\title{
24 The role of biomass \\ use in a defossilised and resource-efficient world
}

\author{
Horst Fehrenbach and Nils Rettenmaier
}

\section{Introduction}

There is limited potential on this planet not only for fossil energy resources but also for any kind of renewable energy. Apart from technical restrictions, each source is also reaching its ecological limits. These can always be attached to the available area. However, no energy source is as closely tied to the available area as biomass. No other renewable energy source has such clear use restrictions with regard to planetary boundaries as biomass. On the other hand, the production and use of biomass are essential components of life. The use of biomass by humans is as old as humankind itself and is the source for satisfying a wide range of needs, from nutrition through building and utility material to energy.

Based on the energy demand of the industrialised countries, the almost uncontroversial expansion of the use of biomass for energy purposes ten years ago has now been massively questioned as a sustainable solution. Haberl et al. (2007) calculated that Europe is already using considerably more productive ecosystem services (net primary production) worldwide than it can mobilise on its territory. The German Federal Environment Agency (UBA) acknowledged this conclusion and stated that for covering the high energy consumption in the industrialised countries of the world by the cultivation of biomass disproportionately large proportions of productive arable (Jering et al. 2012). There is undoubtedly a general consensus that food production should be given priority under all circumstances. All the more so as food security in the future will face major challenges, given the further increase in the world population and global food trends (e.g. more animal products that require many times more land than plant-based products).

Particularly with regard to the globalisation of agricultural markets, there are also socio-economic implications which have been intensively discussed in the relevant research on the sustainability assessment of bioenergy in recent years. Increased demand for bioenergy in addition to increasing food markets has been spotted as a driver for an additional increase in land-use change (Laborde 2011). Furthermore, in globalised agricultural markets, such land-use change can appear detached from the actual areas on which the raw materials 
are produced. This principle is described as indirect land-use change (iLUC). Intensified, yield-only management of forestry land also leads to adverse effects, particularly in the area of biodiversity. Nevertheless, the use of biomass in current energy systems (electricity, heat, fuel) contributes significantly to the share of renewable energies. The current European renewable energy policy enhances the biofuel targets for 2030 (European Parliament \& Council of the European Union 2018), but fuels with low risk for land-use change shall be given preference.

In view of the above-mentioned limits, the objective of this article is to critically reflect on which role biomass could play in a defossilised and resource-efficient world and to what extent biomass can be provided with low risk for land-use change.

\section{Biomass with low risk for land-use change}

The food versus fuel debate of the past ten years focussed a lot on land-use changes that directly or indirectly might be triggered by increasing demand for crop-based biofuels and bioenergy. It has become clear that land-use changes can only be minimised (or ideally mitigated) by either using biogenic waste and residues or biomass from dedicated crops with low risk for land-use change.

While there is little doubt about the sustainable use of biogenic waste and residues, there is still an ongoing discussion about potential loopholes associated with the use of so-called low iLUC biofuels and bioenergy based on dedicated crops. It is widely held that (indirect) land-use change can be mitigated through (i) yield increases due to improved agricultural practices (beyond levels which would have prevailed in the absence of productivitypromoting schemes for non-food biomass), as well as (ii) the cultivation of crops on land not previously used for the cultivation of crops (e.g. preamble of European Parliament \& Council of the European Union 2018). However, this will only lead to a reduced (i) LUC risk if stringent criteria regarding the additionality of such measures are implemented.

Biomass feedstock with low land-use change risk can thus consist of:

- biogenic waste and residues;

- biogenic residues from agriculture, forestry, landscape management (primary residues);

- biogenic residues from industrial processes (secondary residues); and

- $\quad$ true biogenic waste (tertiary residues).

Dedicated crops (energy/industrial crops) cultivated on:

- $\quad$ unused land (land not used for the cultivation of crops for at least a number of years);

- $\quad$ surplus land (becoming available due to yield increases beyond BAU); 
- the potentials of these two primary sources of low LUC risk biomass are presented in the following two sections; and

- biomass potentials from dedicated crops with low land-use change risk.

As mentioned in the previous section, there are two options of obtaining biomass from dedicated crops with low land-use change risk: i) biomass cultivated on so-called surplus land and ii) biomass cultivated on unused land. These options are discussed in the following.

\section{Biomass feedstock cultivated on unused land}

Unused land is land which was previously not used for the cultivation of crops (cf. definition in European Parliament \& Council of the European Union 2018). It is unclear whether the land hasn't been used at all (in this case the definition could even include pristine land) or whether the land is idling for more than a certain number of years (e.g. five years) after ceasing its agricultural use for economic, political or environmental reasons. In the latter case, the term abandoned (agricultural) land would be more appropriate. Apart from unused land and 'abandoned land', there are many other similar terms that are often incorrectly used as synonyms such as degraded land, wasteland or marginal land. Marginal land is often incorrectly used as an umbrella term for all types of land ranging from fallow and abandoned land to degraded land.

However, since the term marginal originates from economics, it is clear that the extent of land defined as marginal could vary subject to the prevailing economic framework conditions. Therefore, a number of completed and ongoing EU-funded projects such as SEEMLA, FORBIO and MAGIC have focussed their research efforts on marginal land, among others trying to come up with a more stable delimitation based on biophysical criteria.

Within the SEEMLA project, marginal lands in Europe have mapped and quantified using the Muencheberg Soil Quality Rating (SQR) system (Mueller, Schindler, Behrendt, Eulenstein \& Dannowski 2007). According to Vlachaki et al. (2018), approximately 224 Mha of land in Europe belongs to the poor and very poor classes of the SQR index and is identified as marginal. This area corresponds to $45 \%$ of the overall area investigated. Subsequently, the area of marginal land suitable for biomass cultivation was determined (54 Mha) and lastly, the area of marginal land suitable for cultivation of the selected energy crops was quantified (46.5 Mha).

Using a similar GIS-based approach and using biophysical criteria to identify so-called 'areas with natural constraints' (ANC), von Cossel et al. (2018) have mapped and quantified marginal lands in the EU28 within the MAGIC project. Despite a smaller geographical focus (EU28 vs 39 European countries in SEEMLA), the authors identify an area of 64.7 Mha of marginal arable land (53.5 Mha of which influenced by soil constraints according to von Cossel et al. 2019) and report an area of marginal land suitable for cultivation of the selected energy crops of 61.0 Mha. 
For Germany, the reported areas are not in line either: according to Vlachaki et al. (2018), the area of marginal land is 3.2 Mha compared to 5.6 Mha underlying the analysis by von Cossel et al. (2018). The observed discrepancies between the two approaches - especially at EU/European level clearly call for more research and harmonisation.

However, even if the range of results could be narrowed in the future, such analyses based on biophysical criteria still do not tell (i) which share of the land identified as marginal is unused and (ii) whether this land is high carbon stock or highly biodiverse land.

Answering these urgent questions currently is subject to further research since it is clear that only the use of unused, low carbon stock and low biodiversity marginal land avoids indirect land-use changes (iLUC) and negative environmental impacts. Moreover, there are also other alternatives to use marginal land, for example, for other renewable energy sources such as ground-mounted photovoltaic (PV) systems, some of which offer several times greater environmental benefits than biomass production. Last but not least, marginal land is also one of the last retreats for species that already suffer from the intensive use of standard agricultural land (Geffroy 2018; Hallmann et al. 2017), i.e. marginal land plays a vital role in biodiversity conservation. A broad public discussion is therefore needed as to which proportion of marginal land should be reserved for different competing societal objectives such as bioenergy production, other renewable energies or nature conservation (Rettenmaier, Schmehl, Gärtner \& Reinhardt 2018).

Yet, even if the above-mentioned challenge to determine the area of unused, low carbon stock and low biodiversity marginal land was mastered, the result would only represent a static snapshot. In a dynamic world with global population projected to reach 9.7 billion people by 2050 (United Nations 2015) and changing diets due to economic development, significant cropland expansion is expected, to satisfy the additional demand for food and feed. Thus, using feedstock from unused land areas that would have been converted to cropland anyway (in a business-as-usual counterfactual scenario) would lead to indirect land-use changes. Searle and Giuntoli (2018) suggest using Clean Development Mechanism (CDM) methodology for demonstrating additionality, for example, to demonstrate that the unused land would have remained unused or that conversion of the land would not be profitable without biofuel incentives.

On top of all the above-mentioned issues, further research is also needed to determine potential yields on such land. Only then can the biomass potential of dedicated crops from marginal land be appropriately assessed. Yet, it is clear that marginal lands give marginal yields. The authors therefore conclude that the biomass potential from marginal lands in Europe will only contribute relatively little to meet ambitious targets for biofuels and bioenergy.

\section{Biomass feedstock cultivated on surplus land}

Surplus land is land that is not needed any more for food and feeds production due to yield increases as a result of improved agricultural practices 
(mainly intensification). Since crop yields tend to increase over time due to technological and agronomical improvements, only additional yield increases beyond a business-as-usual counterfactual scenario would lead to a reduced (i) LUC risk. Again, Searle and Giuntoli (2018) suggest applying CDM methodology to demonstrate additionality by identifying genuinely abovebaseline yield increases. To the authors' knowledge, this additionality test has not been used in practice yet. Therefore, it is currently impossible to estimate the biomass potential from surplus land in Europe.

\section{Biomass potentials from biogenic waste and residues}

In recent years, numerous studies have been conducted on biomass potentials for energy use, particularly with regard to the available biomass based on biogenic waste and residues (Brosowski et al. 2015; Fritsche et al. 2004; Zeller et al. 2012). Fehrenbach et al. (2019) have examined this work in a comprehensive analysis regarding the comparability of results and approaches. The results revealed the existence of considerable differences even in the definition of biomass potential. The choice of criteria that restrict the physically available potential is critical. The cited meta-study worked out a usable potential for Germany, which includes both the technical limits and demanding ecological restrictions.

\section{Types of biogenic waste and residues}

Following material groups can be distinguished:

- $\quad$ wood from forestry;

- residues from agriculture (including straw, other harvest residues, slurry, manure, among others);

- municipal and commercial biogenic waste and residues (biowaste, yard and garden waste, sewage sludge, waste wood, among others);

- material flows from landscape management (cuttings, among others); and

- industrial biogenic waste (saw dust, black liquor, waste from food industry, among others).

The definition of what is to be understood in many studies as the potential of so-called residual forest wood is very inconsistent. It is often understood to mean small pieces of leftover from the harvesting of wood, which is counted as potential. However, the extraction of these material fractions is viewed critically from the point of view of biodiversity protection and the conservation of nutrients.

Fehrenbach et al. (2019) avoid the term residual forest wood for two reasons and refer to forest wood restricting the actual potential for energy use by excluding the small-sized assortment $(<7 \mathrm{~cm})$. Therefore, the relevant quantities of forest wood already used for energy purposes are to be counted as solid 
wood $(>7 \mathrm{~cm})$ or low-value roundwood that is not used in the sawmill industry for economic reasons. Fehrenbach et al. (2019) refer exactly this material applying the term dendromass for the potential determination. A distinction was then made between the material dendromass part and the energetically usable part taking the request of paper and board industry into account. Under consideration of exactly these criteria, Ewald et al. (2017) specify the energy wood potential with $1.8 \mathrm{~m}^{3}$ per hectare and year.

\section{Quantities of biogenic waste and residues in Germany}

The various biomass potential studies show considerable bandwidths for individual residual materials. For forest wood, there is about a factor of 3 between the lower end of 8 million tonnes (Fritsche et al. 2004) and the higher end of 30 million tonnes (Brosowski et al. 2015), adding current energetic use and additional potential. For straw, the bandwidth is even a factor of 4 , ranging from 5 million tonnes per year (Fritsche et al. 2004) to 20 million tonnes (Zeller et al. 2012). Fehrenbach et al. (2019) evaluated 50 studies and applied a number of criteria to derive the final quantity according to demanding ecological restrictions, as mentioned above. A selection of the criteria applied is listed in Table 24.1.

In order to determine the total energy potential for energy recovery from all residual and waste materials, the estimated quantities are converted from tonne data into a primary energy potential (petajoule, $\mathrm{PJ}$ ). The conversion is made either by the lower calorific value or by the specific gas formation rate. The second applies for waste/residues with negative calorific value due to their high water content and which are used energetically by fermentation.

In this way, the average potential of available primary energy based on biogenic waste and residues of $900 \mathrm{PJ}$ per year is determined. If the collection

Table 24.1 Selection of the criteria applied to determine the potential of residual biomass under demanding ecological restrictions

\begin{tabular}{ll}
\hline Criteria referring to agricultural residues & Criteria referring to forest wood \\
\hline $\begin{array}{l}\text { No land-use change } \\
\text { Consideration of organic farming with }\end{array}$ & $\begin{array}{c}\text { Clear cutting ban } \\
20 \% \text { area }\end{array}$ \\
$\begin{array}{c}10 \% \text { natural forest development in } \\
\text { state-owned forests } \\
\text { Safeguarding nutrient balances and humus } \\
\text { balancing }\end{array}$ & $\begin{array}{c}\text { Consideration of nature conservation } \\
\text { areas }\end{array}$ \\
Consideration of ecological conservation & Consideration of forest certifications \\
compensation areas & Biodiversity goals in used forests \\
Yield increases & Limit for non-solid wood $(<7 \mathrm{~cm})$ \\
Competition for use & \\
Development of livestock & \\
Consideration of grazing livestock & \\
husbandry & \\
\hline
\end{tabular}


of solid manure and various industrial substrates is intensified, the amount can be increased to 960 PJ. If the restriction on the extraction of forest wood is tightened, the total potential is reduced to $880 \mathrm{PJ}$. This amount of energy does not correspond to the final usable energy (electricity, heat, fuel). For this purpose, the conversion losses of the respective conversion techniques must first be included.

\section{Additional bioenergy potential from biogenic waste and residues in Germany}

The analysis of Fehrenbach et al. (2019) does not answer the questions to what extent the available biomasses already used in the energy system. Nevertheless, the study provided indications since the literature on the status quo of use has also been considered. Figure 24.1 compares the potential determined by Fehrenbach et al. (2019) with the quantities that are already energetically used.

Three groups can be distinguished here:

1 Those materials that are already used to a greater extent than the sustainably available potential provides for; this group includes the woody biomasses, in particular, forest wood.

2 Those materials that are already used to the extent that they are actually generated; this group includes a number of municipal and industrial waste types.

3 Those materials that still have an untapped potential; this applies primarily to straw group includes but also to solid manure and other agricultural residues.

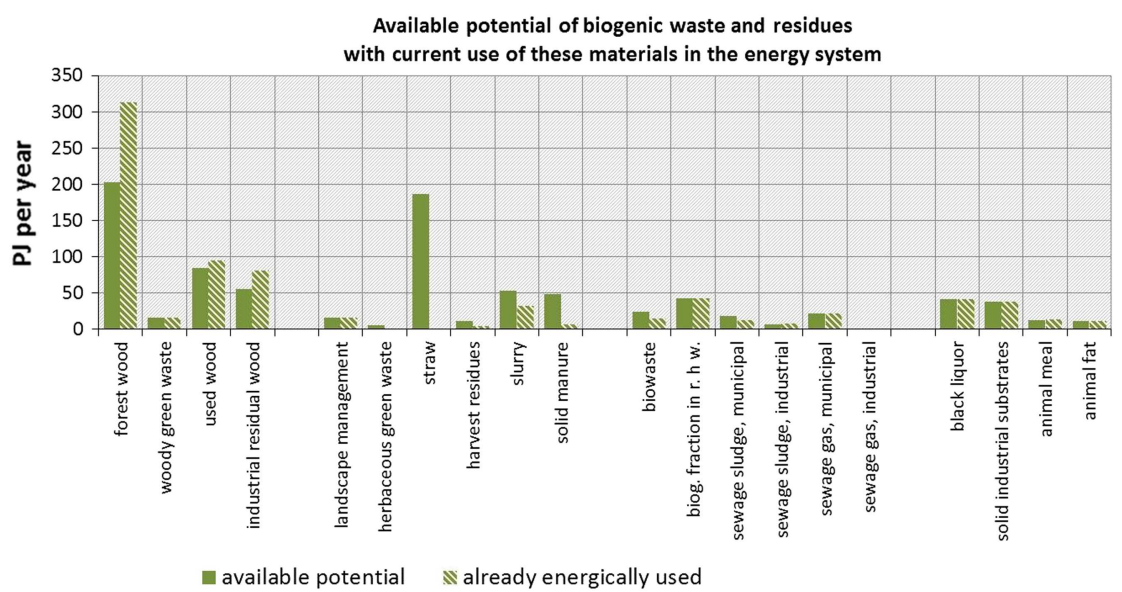

Figure 24.1 Comparing the available potential of biogenic waste and residues with current use of these materials in the energy system.

Source: own illustration based on data from Fehrenbach et al. (2019). 
While Fehrenbach et al. (2019) figure out 900 PJ as the available potential of biogenic residues and waste, approximately $770 \mathrm{PJ}$ are already in some form of energetic use. In the case of forest wood, the potential is even clearly overused so that a reduction would be necessary here. Moreover, a large share of the forest wood a large proportion of the forest wood utilised for energy purposes is used as logs for heating buildings. Against this utilisation pathway, however, the production of industrial process heat shall be preferred.

On the other hand, there is a significant additional potential for the energetic use of straw. Of the 190 PJ (equivalent to 13 million tonnes) determined to be available, only less than 1 per cent has so far been used for electricity, heat and fuel production.

All in all, there remains an additionally available net potential of $130 \mathrm{PJ}$ and the recommendation to redirect parts of currently used biomass into priority paths (process heat, fuels for aviation or shipping).

Thrän et al. (2019) come to very similar figures as far as the technical biomass potential for biogenic residues and waste is concerned. They estimate $876 \mathrm{PJ}$ as the sum of already used and still mobilisable materials.

Future avenues for biomass use are:

- bioenergy and biofuels from biogenic waste and residues in Germany; and - matching biomass types and utilisation paths

To identify preferred utilisation paths in the electricity, heat and fuel markets, the technical and economic boundary conditions of current and future conversion technologies must be analysed. Against this background, available and future technological concepts for the production of secondary and final energy sources for bioenergy sources based on biogenic waste and residues needs to be analysed and evaluated from a process engineering, environmental and economic point of view. To this end Fehrenbach et al. (2019) evaluated a total of 19 technologies according to their suitability of the selected techniques for converting waste or residues into electricity, heat or fuels for transport.

The evaluation was carried out on the basis of the following five criteria, rated after a 3-scale value level:

- $\quad$ Energy efficiency (including exergy as a measure).

- Greenhouse gas balance (saving against fossil reference).

- Production costs (compared to fossil reference).

- Other ecological aspects, such as air pollutants, pollution of water or soils, risk due to further waste streams, the closing of material cycles.

- Compatibility for the transformation of the energy system (relevance regarding substitution of fossil fuels, usefulness for the energy system, storage capability, flexibility).

The pathways for the use in the heat sector achieve the best rating for a total of almost $90 \%$ of the energetic potential of waste and residues. In absolute 
numbers, the output is approximately 600 PJ heat. However, this beneficial result is only valid for direct energetic use in a boiler plant or a combined heat and power plant with the generation of process heat. In the case of residential heat the use of biomass is less favourable, in particular, because of available renewable alternatives (solar, heat pump, insulation) and increased air pollutant emissions. On the other hand, there are mostly no renewable alternatives available for process heat demand in the industrial sector.

For the waste or residues associated with higher moisture contents, the production of biomethane, predominantly for transport fuel production (to which $10 \%$ of the input is attributed, resulting in 25 PJ fuel) is the best evaluated option. Here, too, the favourable rating applies under the condition of a special use: The use of fuels in aviation or shipping, since here renewable alternatives are more difficult to implement than in road transport.

The stability of the results the set boundary conditions of the evaluation approach was varied in the sense of a sensitivity analysis. A significant change in the ranking occurs if the criterion production cost is excluded from the evaluation. The energy use to be preferred will then be allocated to only $55 \%$ industrial heat (370 PJ), 38\% as fuels for transport (190 PJ) and 7\% for electricity generation (16 PJ).

\section{Matching bioenergy supply and energy demand in Germany}

The analysis of Fehrenbach et al. (2019) follows a bottom-up approach. They do not question whether the potential quantities of the most suitable target uses assigned based on a list of criteria are also in demand there to the same extent. Nor are these prioritised utilisation pathways aligned with the scenarios for a Resource-Efficient and Greenhouse-Gas-Neutral Germany (RTD) or the long-term and climate change scenarios for Germany (Pfluger, Tersteegen \& Franke 2017).

After the completion of the study, we now examined how the energy sources allocated to the utilisation pathways correspond to the demand in these sectors. Figure 24.2 shows that both the demand for industrial process heat and aviation fuel is significantly higher than the supply that can be covered by biomass. The metal industry alone requires approximately 550 PJ of process heat at high or medium temperature. The chemical industry has a demand of about 360 PJ (Pfluger et al. 2017). Biomass is an attractive option for industry to avoid greenhouse gases. It allows heat to be transferred to a relatively high temperature level (depending on the calorific value), as well as being available in various aggregate states.

\section{The role of biomass in forward-looking scenario studies}

Biomass plays a vital role in most forward-looking scenario studies using energy systems models such as Pfluger et al. (2017), Gerhardt et al. (2015) or 


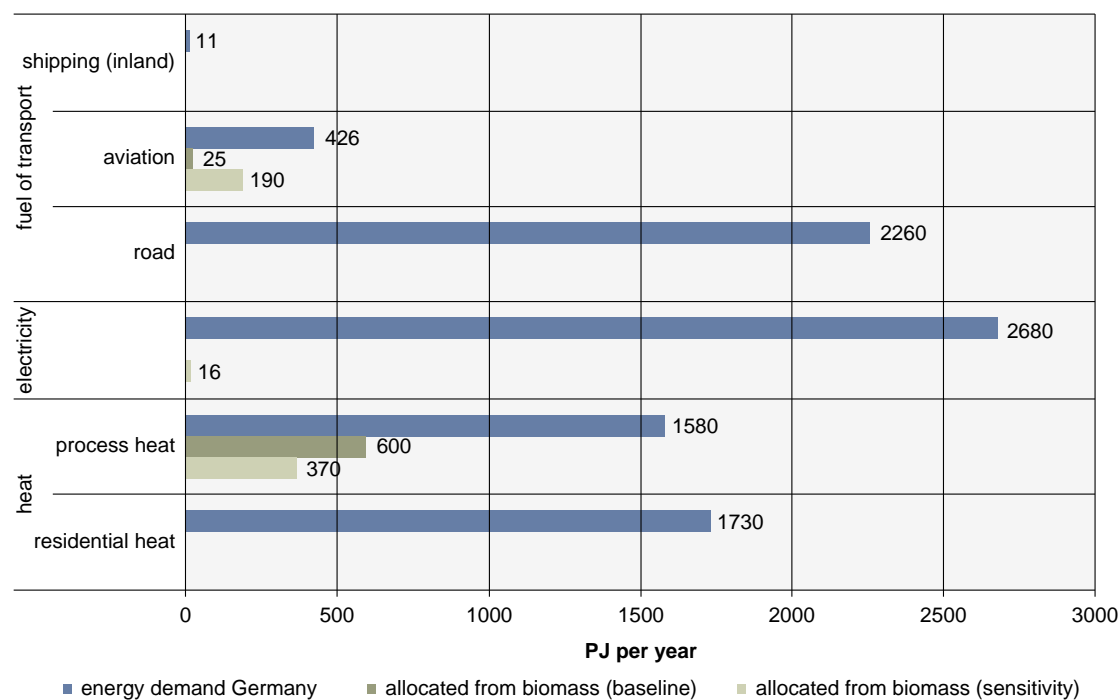

Figure 24.2 Comparing the useful energy from available potential of biogenic waste and residues with the current demand of heat, electricity and transport fuel. Baseline: biomass allocated according to the evaluation by five criteria (see text); sensitivity: evaluation without the criteria production costs.

Source: own illustration based on data from Fehrenbach et al. (2019), Pfluger et al. (2017), AG Energiebilanzen e.V. (2019).

Repenning et al. (2015). These studies differ in terms of underlying biomass potentials (biogenic waste and residues, available land for the cultivation of dedicated crops as well as the amount of biomass imports) and biomass allocation to the various sectors. In Günther et al. (2019), no use at all of the dedicated crops is foreseen in the future (see also Chapters 12 and 13 of this volume). All studies conclude that biomass should primarily be used in those sectors where there are no or few affordable alternatives for decarbonisation, respectively defossilisation. Most often, aviation and shipping, as well as hightemperature heat for industrial processes, are mentioned as the main future applications. But also the chemical industry must not be neglected which needs a renewable carbon source in the future This could either be recycled carbon via $\mathrm{PtG} / \mathrm{PtL}$ (especially for short chain-length molecules) or biomass, from which longer, more complex molecules synthesised by nature could be obtained.

\section{Conclusions}

The role of biomass in a future without fossil $\mathrm{CO}_{2}$ emissions is complex. On the one hand, biomass is a readily available resource and should also be used within the framework of a resource-efficient economy. On the other hand, 
biomass potentials are limited by various factors. Biomass production is linked to land area, which - given the growing world population - must be used for food supply first. For this reason, the potential for non-food uses of biomass from dedicated crops will always be sharply limited.

Yet, there is a potential of dedicated crops from marginal land or surplus land with low risk for indirect land-use change (iLUC). As these land categories have not yet been clearly defined, data on potentially available areas are therefore not comparable. In addition, conflicts with biodiversity often arise when these types of land are used. Moreover, the yields from marginal areas are marginal. The realisation of greater potential for the use of these areas is therefore not to be expected.

The question of how much forest wood is available is a particularly complex one: even the distinction between wood as the actual harvested good and what is called residual forest wood is unclear. The decisive factor is the forestry strategy: is the forest rather a production site for maximised wood yield or a near-natural ecosystem with high carbon storage? If priority is given to the second option, the potential for use is also significantly lower here. Besides, there are the imponderables of forest restructuring and climate change, which may result in a high volume of timber in the short term. The long-term potential may continue to decline.

Among the multitude of different biogenic wastes and residues, straw accounts for the largest unused energy potential to date. The more recent studies estimate this at a range of 140 to 200 Petajoules. Manure also offers the possibility of expanding the production of biogas. Otherwise, the majority of substances are already used for energy.

On the way to a climate-neutral world, biomass thus makes a contribution to directly replacing fossil fuels. The results presented here on the potentials of biogenic waste and residues as well as of cultivated biomass on unused and surplus land show that it is difficult to increase the domestic biomass supply compared to today. According to most forward-looking scenario studies, the future biomass demand for energy in the sectors transport (aviation and marine fuels) and industry (high-temperature heat) will remain high or even rise. Besides these, the demand for biomass for material use, e.g. in the chemical industry, could continue to rise. It is clear that biomass demand will exceed domestic biomass supply, so significant biomass imports may be necessary. Alternatively, the demand for hydrocarbons for fuels and chemicals could also be met by $\mathrm{PtG} / \mathrm{PtL}$ technologies, but at significantly higher costs (also in the future). Biomass should, therefore, be used in particular where there are no, or only a few, very expensive renewable alternatives available. To answer this question, further research activities are needed to determine more precisely the future role of biomass in a defossilised world.

\section{Abbreviations}

ANC Areas with Natural Constraints (Articles 31 \& 32 in European Parliament \& Council of the European Union 2013)

BAU business as usual 
CDM Clean Development Mechanism, one of three market-based mechanisms under the Kyoto Protocol

EU European Union

GIS Geographical Information System

iLUC indirect land use change

LUC land use change

PJ petajoule

PtG power-to-gas

PtL power-to-liquid

PV photovoltaics

RED II Renewable Energy Directive II (European Parliament \& Council of the European Union 2018)

RTD Ressourceneffizientes und treibhausgasneutrales Deutschland (Resource-Efficient and Greenhouse-Gas-Neutral Germany) (Günther et al. 2019)

SQR (Muencheberg) Soil Quality Rating (Mueller et al. 2007)

\section{References}

AG Energiebilanzen e.V. (2019). Energiebilanz der Bundesrepublik Deutschland 2017. Retrieved 19 June 2019 from https://ag-energiebilanzen.de/index.php?article_id=29\& fileName $=$ bilanz17d.xlsx.

Brosowski, A., Adler, P., Erdmann, G., Stinner, W., Thrän, D., Mantau, U., ... Reinholdt, G. (2015). Biomassepotenziale von Rest- und Abfallstoffen (Status quo in Deutschland). Schriftenreihe Nachwachsende Rohstoffe (Vol. 36). Gülzow-Prüzen, Germany: Fachagentur Nachwachsende Rohstoffe e.V. (FNR). Retrieved from https://mediathek.fnr.de/ downloadable/download/sample/sample_id/1251/.

European Parliament \& Council of the European Union. (2013). Regulation 2013/1305/ EU on support for rural development by the European Agricultural Fund for Rural Development (EAFRD) and repealing Council Regulation (EC) No 1698/2005. Official Journal of the European Union, 56(L 347), 487-548. Retrieved from http://eur-lex.europa. eu/legal-content/EN/TXT/?uri=celex:32013R1305.

European Parliament \& Council of the European Union. Directive (EU) 2018/2001 of the European Parliament and of the Council of 11 December 2018 on the promotion of the use of energy from renewable sources (recast), Official Journal of the European Union, (L 328), 82-209. Retrieved from https://eur-lex.europa.eu/legal-content/EN/TXT/PDF/? uri $=$ CELEX:32018L2001.

Ewald, J., Rothe, A., Hansbauer, M., Schumann, C., Wilnhammer, M., Schönfeld, F., ... Zahner, V. (2017). Energiewende und Waldbiodiversität. BfN-Skripten (Vol. 455). Bonn, Germany: Bundesamt für Naturschutz (BfN).

Fehrenbach, H., Giegrich, J., Köppen, S., Wern, B., Pertagnol, J., Baur, F., ... Wiegmann, K. (2019). BioRest: Verfügbarkeit und Nutzungsoptionen biogener Abfall- und Reststoffe im Energiesystem (Strom-, Wärme- und Verkehrssektor). UBA Texte (Vol. 115/2019). Dessau-Roßlau, Germany: Umweltbundesamt (UBA). Retrieved from www.umweltbundesamt.de/sites/default/files/medien/ 1410/publikationen/2019-09-24_texte_115-2019_biorest.pdf. 
Fritsche, U., Dehoust, G., Jenseit, W., Heinz, A., Thrän, D., Reinhardt, G., ... et al., (2004). Stoffstromanalyse zur nachhaltigen energetischen Nutzung von Biomasse [Material Flow Analysis of Sustainable Biomass Use for Energy]. Darmstadt, Germany: Öko-Institut e.V. Retrieved from www.oeko.de/oekodoc/236/2004-025-de.pdf.

Geffroy, L. (2018). Where Have all the Farmland Birds Gone? CNRS Le Journal. Retrieved from https://news.cnrs.fr/articles/where-have-all-the-farmland-birds-gone.

Gerhardt, N., Sandau, F., Scholz, A., Hahn, H., Schumacher, P., Sager, C., ... Müller, T. (2015). Interaktion EE-Strom, Wärme und Verkehr. Kassel, Germany: FraunhoferInstitut für Windenergie und Energiesystemtechnik (Fraunhofer IWES). Retrieved from www.iee.fraunhofer.de/content/dam/iee/energiesystemtechnik/de/Dokumente/ Veroeffentlichungen/2015/Interaktion_EEStrom_Waerme_Verkehr_Endbericht.pdf.

Günther, J., Lehmann, H., Lorenz, U. \& Purr, K. (2019). A resource efficient pathway towards a greenhouse gas neutral Germany. Dessau-Roßlau, Germany: Umweltbundesamt (UBA). Retrieved from www.umweltbundesamt.de/sites/default/files/medien/376/publikationen/ 190212_uba_fachbrosch_rtd_engl_bf_low2.pdf.

Haberl, H., Erb, K. H., Krausmann, F., Gaube, V., Bondeau, A., Plutzar, C., ... FischerKowalski, M. (2007). Quantifying and mapping the human appropriation of net primary production in earth's terrestrial ecosystems. Proceedings of the National Academy of Sciences of the United States of America, 104(31), 12942-12947. https://doi.org/10.1073/pnas. 0704243104.

Hallmann, C. A., Sorg, M., Jongejans, E., Siepel, H., Hofland, N., Schwan, H., ... de Kroon, H. (2017). More than 75 percent decline over 27 years in total flying insect biomass in protected areas. PLoS ONE, 12(10), e0185809. https://doi.org/10.1371/journal.pone. 0185809.

Jering, A., Klatt, A., Seven, J., Ehlers, K., Günther, J., Ostermeier, A. \& Mönch, L. (2012). Globale Landflächen und Biomasse nachhaltig und ressourcenschonend nutzen. UBA Positionen. Dessau-Roßlau, Germany: Umweltbundesamt (UBA). Retrieved from www. umweltbundesamt.de/publikationen/globale-landflaechen-biomasse.

Laborde, D. (2011). Assessing the Land Use Change Consequences of European Biofuel Policies. Washington, DC: International Food Policy Research Institute (IFPRI). Retrieved from http://ebrary.ifpri.org/utils/getfile/collection/p15738coll5/id/197/filename/198.pdf.

Mueller, L., Schindler, U., Behrendt, A., Eulenstein, F. \& Dannowski, R. (2007). The Muencheberg Soil Quality Rating (SQR) Field Manual for detecting and assessing properties and limitations of soils for cropping and grazing. Müncheberg, Germany: Leibniz-Centre for Agricultural Landscape Research (ZALF) e.V. Retrieved from www.zalf.de/de/ forschung_lehre/publikationen/Documents/Publikation_Mueller_L/field_mueller.pdf.

Pfluger, B., Tersteegen, B. \& Franke, B. (2017). Langfristszenarien für die Transformation des Energiesystems in Deutschland. Berlin, Germany: Bundesministeriums für Wirtschaft und Energie (BMWi). Retrieved from www.bmwi.de/Redaktion/DE/Artikel/Energie/ langfrist-und-klimaszenarien.html.

Repenning, J., Emele, L., Blanck, R., Dehoust, G., Förster, H., Greiner, B., ... Ziesing, H. (2015). Klimaschutzszenario 2050. Berlin, Germany: Öko-Institut e.V. Retrieved from www.oeko.de//oekodoc/2441/2015-598-de.pdf.

Rettenmaier, N., Schmehl, M., Gärtner, S. \& Reinhardt, G. (2018). Final report on environmental assessment covering LCA \& LC-EIA (supported by the EU's Horizon 2020 programme under GA No. 691874). SEEMLA project reports. Heidelberg, Germany: IFEU - Institute for Energy and Environmental Research Heidelberg. Retrieved from http://seemla.eu/en/project-deliverables/. 
Searle, S. \& Giuntoli, J. (2018). Analysis of high and low indirect land-use change definitions in European Union renewable fuel policy. Washington, DC: International Council on Clean Transportation (ICCT). Retrieved from https://theicct.org/sites/default/files/ publications/High_low_ILUC_risk_EU_20181115.pdf.

Thrän, D., Lauer, M., Dotzauer, M., Oehmichen, K., Majer, S., Millinger, M. \& Jordan, M. (2019). Technoökonomische Analyse und Transformationspfade des energetischen Biomassepotentials (TATBIO). Leipzig, Germany: Deutsches Biomasseforschungszentrum (DBFZ). Retrieved from www.bmwi.de/Redaktion/DE/Publikationen/Studien/technooekonomische-analyseund-transformationspfade-des-energetischen-biomassepotentials.html.

United Nations. (2015). World Population Prospects. Key Findings and Advance Tables. 2015 Revision. New York, NY: United Nations Department of Economic and Social Affairs, Population Division. Retrieved from http://esa.un.org/unpd/wpp/ Publications/Files/Key_Findings_WPP_2015.pdf.

Vlachaki, D., Gounaris, N., Dimitriadis, E., Galatsidas, S., Gerwin, W., Repmann, F., ... Volkmann, C. (2018). Final guidelines for the sustainable exploitation of MagLs for bioenergy (Deliverable D6.8). SEEMLA project reports. Orestiada, Greece: Democritus University of Thrace (DUTH). Retrieved from http://seemla.eu/en/projectdeliverables/.

von Cossel, M., Iqbal, Y., Scordia, D., Cosentino, S. L., Elbersen, B., Staritsky, I., ... Lewandowski, I. (2018). Low-input agricultural practices for industrial crops on marginal land (Deliverable D4.1). MAGIC project reports. Stuttgart (Hohenheim), Germany: University of Hohenheim. Retrieved from http://magic-h2020.eu/documents-reports/. von Cossel, M., Lewandowski, I., Elbersen, B., Staritsky, I., Van Eupen, M., Iqbal, Y., ... Alexopoulou, E. (2019). Marginal Agricultural Land Low-Input Systems for Biomass Production. Energies, 12(16), 3123. https://doi.org/10.3390/en12163123.

Zeller, V., Thrän, D., Zeymer, M., Bürzle, B., Adler, P., Ponitka, J., ... Wiegmann, K. (2012). Basisinformationen für eine nachthaltige Nutzung von landwirtschaftlichen Reststoffen zur Bioenergiebereitstellung (DBFZ Report). Leipzig: Deutsches Biomasseforschungszentrum (DBFZ). Retrieved from www.dbfz.de/fileadmin/user_upload/Referenzen/DBFZ_ Reports/DBFZ_Report_13.pdf. 